\title{
EVALUATION OF THE EXPEDIENCY OF TECHNOLOGY COMMERCIALIZATION: A CASE OF INFORMATION TECHNOLOGY AND BIOTECHNOLOGY
}

\author{
Vaida ZEMLICKIENE் ${ }^{*}$, Zenonas TURSKIS \\ Institute of Sustainable Construction, Vilnius Gediminas Technical University, Vilnius, Lithuania
}

Received 23 October 2019; accepted 02 December 2019

\begin{abstract}
The ability to timely and objectively evaluate the expediency of technology commercialising is a crucial step for R\&D organisations. It is a game with business success, which could enable to operate technologies efficiently and prevent unproductive investments. Managers in power, involved in the technology commercialization cycle, create rules for the game and are the leading players. The research establishes specifics of different technological fields, which are essential for assessing the expediency of technology commercialization. The scientific literature of technology commercialization didn't take into account the specifics of different technological fields. The study presents the first two phases of the expediency of commercialization of the information technologies and biotechnologies evaluation models: the development of elements collections and the establishment of the importance of elements. The proposed technique could be expanded to select the most suitable technology for sustainable management of commercialization and the rational use of resources. The results of the expert's survey aimed at establishing the importance of the elements are compared, efforts are made to identify differences in the evaluation the expediency of technology commercialization for information technologies and biotechnologies. The MCDM method has applied the selection of which was established by the motive related to the goal of evaluation - to evaluate the expediency of technology commercialization for information technologies and biotechnologies.
\end{abstract}

Keywords: evaluation expediency of technology commercialization, commercial potential, information technology, biotechnology, the importance of the elements, fuzzy rating, MCDM, Eckenrode method.

JEL Classification: O32.

\section{Introduction}

Active development of modern economy needs well-balanced development of technologies (Hashemkhani Zolfani et al., 2013). Innovation is the foundation of any contemporary economy and any sustainable country. It includes the implementation of innovative ideas, the development of innovative technologies, bringing novel products and services to the market

\footnotetext{
${ }^{*}$ Corresponding author. E-mail: vaida.zemlickiene@vgtu.lt
} 
(Vechkinzova et al., 2019). Product innovation among the different types of innovation is considered to be the most important kind of innovation, it is said to be an antecedent of any firm innovation strategy of the firm (Geldres-Weiss et al., 2018). In contemporary management, every realization of intention to commercialize is very time and financial expenditure consuming. The applicability and effectiveness of new and commonly used technologies in a variety of fields depend on many elements (Zavadskas et al., 2013b). The TCOS framework helps managers and scholars to understand how organizations, supply chains, and communities can better address uncertainties associated with innovations. The TCOS framework proposes that there are four types of innovation uncertainty that must be carefully addressed: a) technological feasibility - existence or not, and possibility to develop the required technology; b) commercial viability - existence or not, and possibility to create a market for the innovation); c) organizational appropriability - the potential to appropriate the benefits of the innovation and how difficult it is for competitors to imitate the innovation; and d) societal acceptability - the potential to have the innovation accepted by society given its societal side-effects, including environmental, social, cultural, and political implications (Silvestre \& Țîrcă, 2019). The organizations performing R\&D activities need to avoid non-effective investments (Bagočius et al., 2014). They assess the commercial potential of technology, to justify decisions on the expediency of technology commercialization. The investigations highlighted that during the evaluation the commercial potential of technologies, it is necessary to take into account the specifics of different technological fields. In this case, a study on information technology and biotechnology are presented. This research paper provides the first two stages of the model's adaptation procedure for evaluation the expediency of technology commercialization: the customization process of element collections to information technology and biotechnology and the outcomes of the experts' survey aimed at identifying the importance of the elements that are ranked and collated. To exploit the best practices of European organizations for research were selected organizations, which are continually participating in the course of technology commercialization in EU countries, and authorities responsible for the promotion and control of technology development. Efforts were made to establish similarities and differences in the evaluation of the commercial potential of these two technological fields, to develop models for evaluating the commercial potential of information technology and biotechnology. These research results will allow achieving a more objective evaluation of the commercial potential for these technological fields and more rational use of resources.

\section{Development the collection of elements for evaluation expediency of technology commercialization}

The first step of the model's adaptation procedure - the creation of a collection of elements to assess the commercial potential of information technologies and biotechnologies. The collection of elements is the foundation to establish the importance of the elements and the meanings of element values in the multi-criteria decision-making (MCDM) methods. Initial collections of elements were developed based on a previously developed universal collection of elements (Zemlickiené, 2015; Zemlickienè et al., 2017) and a literature review dedicated to the specifics of the commercialization of information technology and biotechnologies, and 
the concept proposed by Belton and Stewart (2012). With the help of the authors analysing innovation indicators throughout the innovation process (Dziallas \& Blind, 2019; Pérez et al., 2019), technology commercialization, legal regulation of intellectual property issues and the aspects of different fields of engineering sciences, the authors determined sensitive areas and problems are faced organizations in the process commercialization and create new collections of elements for information technology and biotechnology modifying a previously proposed universal collection of elements. Afterwards, the collections of elements based on the experts' survey were revised and used as the research tool for establishing the importance of elements (Figure 1).

Information technology (IT) is a broad range of technologies based on computing, networking and data storage to processing information at high speed. They are useful in automation, transaction processing, knowledge processes, decision making, problem-solving, control systems, robotics, data analysis, information access and entertainment. Information and Communication Technology (ICT) includes telecommunication infrastructure, such as mobile phone networks with IT.

The smooth market uptake of Information and Communications Technologies (ICT), over the last ten years, has made a significant impact on economic growth worldwide (European Commission, 2010; ITU, 2012). ICT market uptake is treated as the root cause for

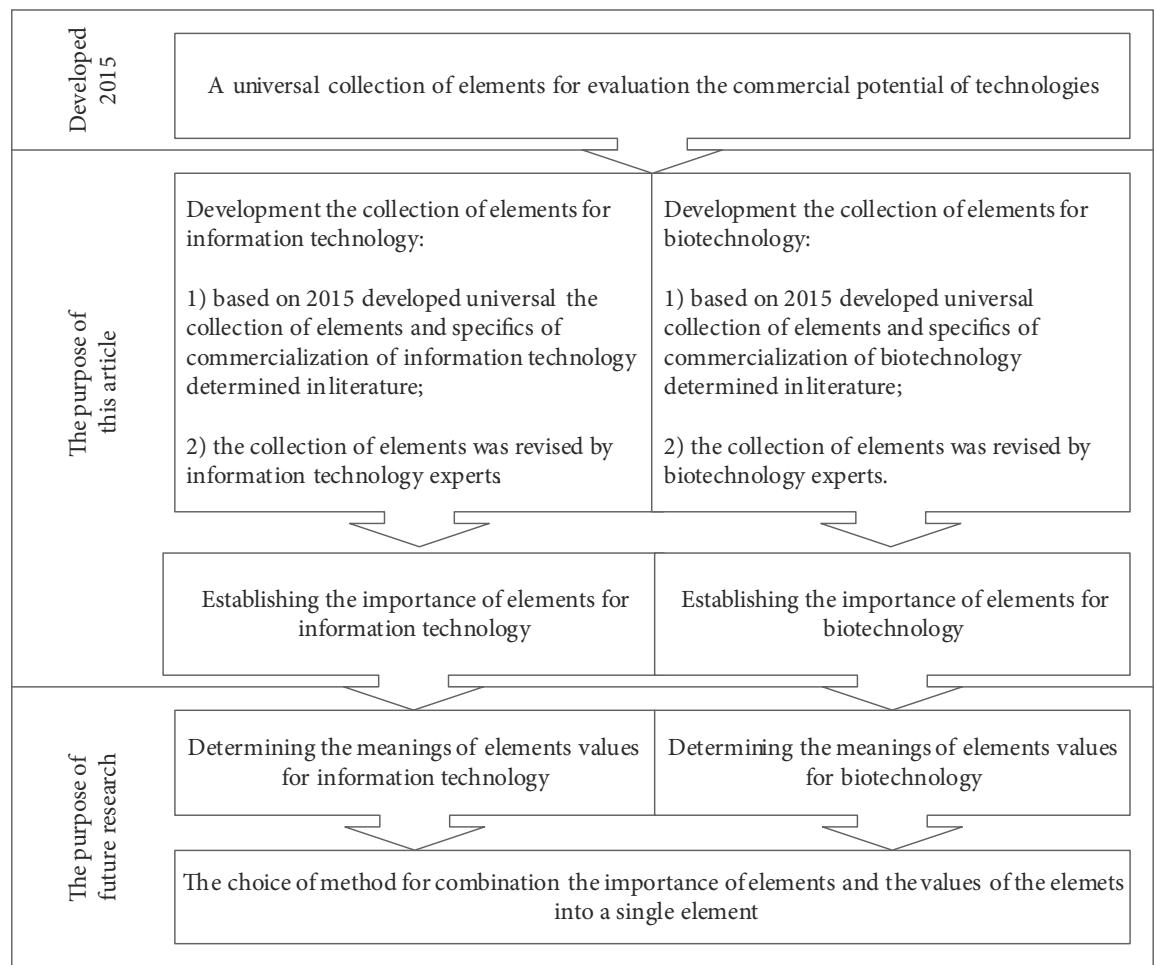

Figure 1. Structure of the study on the evaluation of the commercial potential of information technology and biotechnology 
economic and social progress (Montagnier \& Wirthmann, 2011). Dynamic market uptake of ICTs worldwide influences considerable changes in the economics of countries performance, which is primarily due to the unique features of the products, that changes the ways of doing business and ensure the growth of human and social capital. Products of this field of technology can be quickly adapted, require low cost and little efforts to acquire and usage them - easily installable at zero-marginal cost, fast distributable, omit geographical and infrastructural barriers, claimed to be "for all technologies" (Lechman, 2014).

In the field of ICT, the path of technology development from conception to real product and sale is much shorter if we compare it to biotechnology. For ICT product development time is short and rarely exceeds 18 months. In the field of ICT, companies that have not been ably placed on the market a competitive product over more than three years is on the whole considered to be unsuccessful (Park et al., 2017). For ICT companies, essential costs are variable and utterly dependent on human resources, the main costs of IT development are available costs for human resources. ICT specialists can specialize in different ICT fields like software development, application management, hardware - desktop support, server or storage administrator - and network architecture. Usually, ICT companies looking for employees wide profile or with the overlapping complex of skills (SearchDataCenter, 2018). The process of patenting for different technologies differently interacts with the process of technology development. ICT products are created and marketed so quickly. In such a situation, intellectual protection becomes inexpedient. Just getting international patent protection with the statutory deadlines takes more than two years. For ICT, this is an unbearably long term. Quite often, two or three years after a patent application is filed, ICT becomes outdated and legal protection becomes obsolete. Intellectual property protection becomes obsolete due to the long term for obtaining a patent. For these reasons, many ITC developers submit a patent application only in the last stages of technology development, when the technology is validated, and the company has coaxed enough external capital. It means that patenting does not hinder the development of technology, funds and time needed to develop the technology are not being used at the time. However, rapidly changing technologies such as ICT are still stuck in legal disputes over their patentability.

Concerning the previous collection of elements for the expediency of technologies commercialization and the particularity of ITC, the elements reflecting the specifics of these field of technologies and already included in the collection of elements are:

- In the financial environment group of elements (C): the predicted period of product development (C6);

- In the legal environment group of elements $(G)$ : benevolence of national legislation for commercialization (G1).

- It was decided to include it in the ITC collection of elements:

- legal environment $(G)$ : the consequences of patenting for the development of technology (G6).

Biotechnologists use biological organisms, cells or cellular components, and processes to develop new technologies. New tools and products of biotechnology are useful in research, agriculture, industry and the clinic. It can solve some of the most significant problems in the world, such as providing food for a growing number of people and offering new solutions to the problem of our limited natural resources. The development of biotechnology in the field 
of human and animal health is very complicated, limited by the need for exhaustive safety testing, multistage clinical research and regulatory validation. Because biotechnology has great potential, it has the potential to impact the world. Biotechnology inventions can raise new practical concerns and ethical questions that must be addressed with informed input from all of society. Kiškis and Limba (2016) emphasized that product development time is prolonged due to slow biological and bureaucratic processes. The usual length of product development at least from seven to ten years, and for a maximum from twelve to fifteen years. The patenting process of biotechnologies makes a significant influence for the development process: the steps before the technology reaches the market typically take up a considerable part of the useful patent protection period (Vu et al., 2018). Biotechnology research is costly and requires adequate infrastructure and reagents (Mamzer et al., 2018). The enormous costs and risks make it very difficult to attract investors. The risks involved in biotechnology projects are vast and often high costs are not justified if the technology is not approved at one of the validation steps. Confidentiality is crucial for the commercialization of biotechnology. It should be preserved for a long time, but there is a risk over a long period to reveal this secret (Volpatti \& Yetisen, 2014). The patenting process in biotechnology projects hinders progress at an early and intermediate stage. It competes for financial and time resources that could otherwise to be dedicated to further technology development. The biotechnology mentioned above context is very different from ICT, where the patenting process complements the validated technology development process and is implemented only with the necessary additional resources for patenting (Kiškis \& Limba, 2016).

Based on the specificity of the commercialization of biotechnology, elements included in the previous collection of elements for assessing the commercial potential of biotechnology:

- In elements group financing potential (C1): impact of the potential product durability to create a renewable source of income (C5); predicted period of product development (C6);

- In elements group competitive environment (D): the ability to copy technology (D2);

- In elements group competence of technology developers (F): competence of technology transfer personnel (F3);

- In elements group legal environment $(\mathrm{G})$ : benevolence of national legislation for commercialization (G1).

- Elements are recommended to be included in the collection of elements for assessing the commercial potential of biotechnology:

- In elements group financial environment (C): accessibility of the infrastructure for product development;

- Competences of technology developers (F): accessibility of specialized staff;

- Legal environment $(\mathrm{G})$ : the consequences of patenting for the development of technology.

An experts' questionnaire sent and two-stage survey conducted to construct the collection of elements and establish the relative importance of the elements in the collection. The first step of the study is to compile and validate the final collection of elements. Figures 2 and 3 present a collections of elements for assessing the commercial potential of information technology and biotechnology. Table 2 describes the meanings of elements in the collection. 


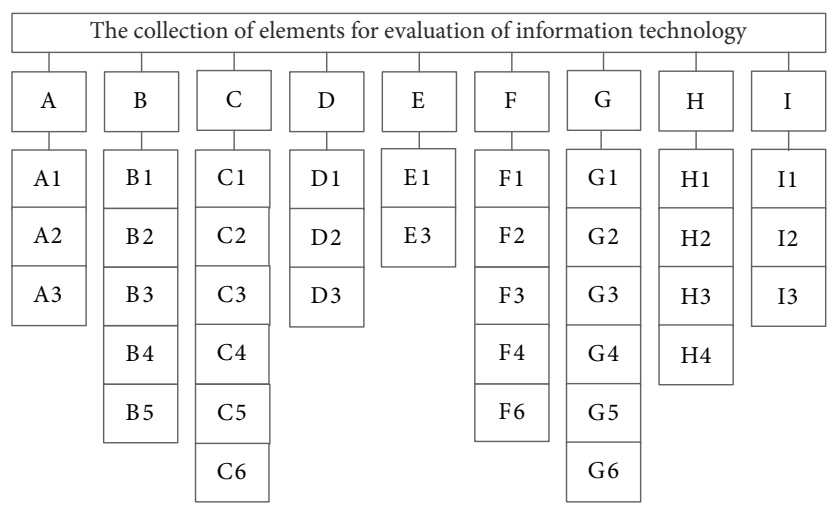

Figure 2. The collection of information technology elements (source: Zemlickienè, 2015; Lechman, 2014; Park et al., 2017, and results of expert research 2018-2019)

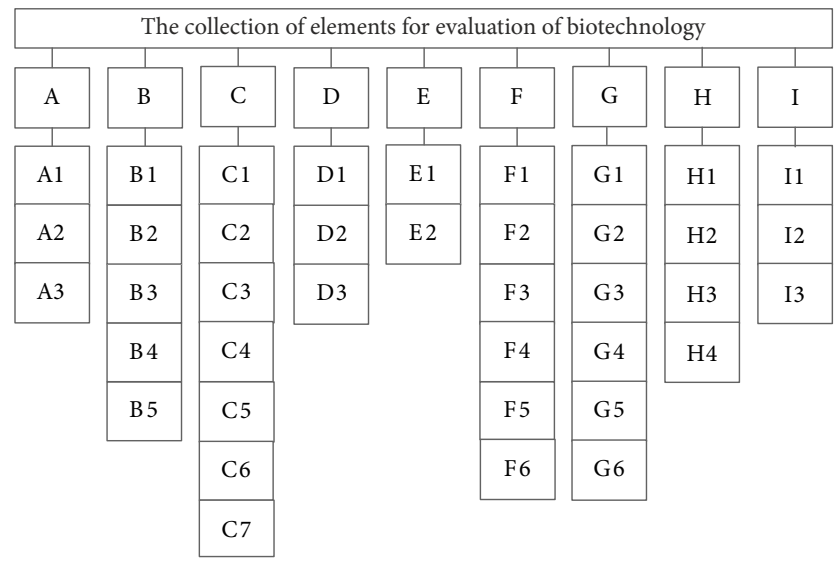

Figure 3. The collection of biotechnology elements (source: Zemlickienè, 2015; Vu et al., 2018; Mamzer et al., 2018; Volpatti \& Yetisen, 2014; Kiškis \& Limba, 2016, and results of expert research 2018-2019)

Experts were selected for this study according to the following criteria: 1) proficiency in the process of technology commercialization in EU countries; 2) positions in organizations and institutions responsible for the promotion and commercialization of technology control.

\section{Establishing the importance of elements for evaluation expediency of technology commercialization}

Successful implementation of technology is considered when all risks are properly managed in all planning stages (Zavadskas et al., 2013a). The selection of proper techniques and strategies to real-life problems depends on multiple players (Maghsoodi et al., 2019) involved in the commercialization of technology. In most cases, a group of experts have no strict and steady idea of the same standards and alternatives. It leads the group of decision-makers to 
vague established situations and models. Besides, most often, the models based on the criteria rating in words (Turskis et al., 2019b, 2019c). Most of the technology management problems include the vague and uncertain importance of criteria (Zavadskas et al., 2013a). The mathematical models could be used when dealing with uncertainty (Whinney, 1971). In $1965 \mathrm{Za}$ deh introduced the fuzzy theory to deal with inaccurate and uncertain data (Zadeh, 1965). It was later useful in many MCDM applications (Buckley, 1984; Leberling, 1981; Turskis et al., 2015). The fuzzy extensions of MCDM models play principal roles in the risks' weighting, responses and choices of means to manage them (Ghassemi \& Darvishpour, 2018).

The decision-making processes are necessary to design and evaluate a collection of different alternatives (Zavadskas et al., 2009). One of the essential tasks is to reject those alternatives that do not meet the lower bounds of the important criteria values. The fuzzy set theory allows decision-makers to use incomplete or partially obtained information into the problem-solving model (Turskis et al., 2012). A fuzzy set is characterized by the most widely used triangular membership function is used in this research (Dubois \& Prade, 1978). Van Laarhoven and Pedrycz (Van Laarhoven \& Pedrycz, 1983) introduced the basic operations of a fuzzy triangular number A fuzzy triangular number will be denoted as $(\alpha, \beta, \gamma)$ ( $\alpha$ - the lower value of a fuzzy number, $\beta$ - modal value of a fuzzy number, $\gamma-$ the upper value of a fuzzy number). Many researchers presented different fuzzy models to solve the issues of technology commercialization.

It is essential to identify the importance of the elements before starting to assess the expediency of technology commercialization. To achieve these experts use criteria weighting methods. Scientists developed dozens of different subjective approaches for assessing weights (Nakhaei et al., 2016): AHP (Saaty, 1980), ANP (Saaty, 1996), expert method (Zavadskas \& Vilutienè, 2006), SWARA (Keršulienè et al., 2010; Keshavarz-Ghorabaee et al., 2018), etc. Different types of measurement scales (nominal, ratio, ordinal, interval, or fuzzy) could be used to measure the importance of criteria. Likert introduced Likert scales in 1932 (Likert, 1932). The Likert-type scale is an easy-to-use instrument. They could be effectively analysed as interval or fuzzy scales (Allen et al., 2017).

In 1965 Eckenrode offered an original technique to rating the importance of elements (Eckenrode, 1965). Rating is useful for technologies evaluation, and it's especially effective for decision making. Modified Eckenrode's Rating method applying the basics of fuzzy sets theory is selected to the case study (Turskis et al., 2019a). At the beginning of the problem-solution experts established the main elements influencing the expediency of technology commercialization. Each of the elements differently affects technology and therefore has different importance in these problems solving. The Likert-type scale made below for the importance of the element's (Figure 4).

In the second stage, the experts expressed their position on the importance of elements. By assessing the importance of elements, the direct expert evaluation of the importance was applied, and a ten-point scale was used. In this case, the most important element receives the highest point, whereas the least important the lowest one. During the carried out research, forty-four correctly completed questionnaires were received: twenty-two questionnaires for information technology and twenty-two for biotechnology. 


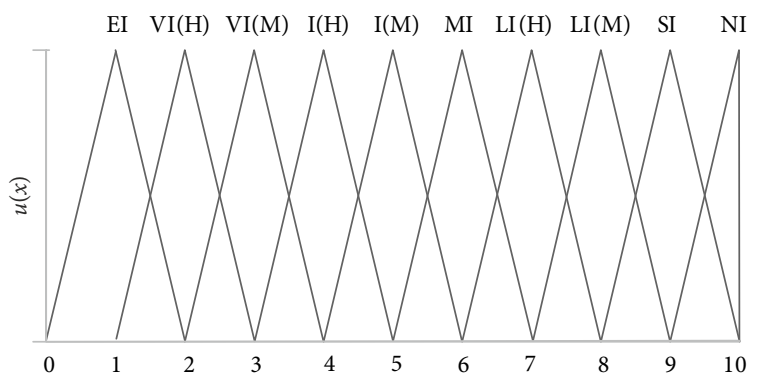

Figure 4. Likert-type ten-point scale to establish the importance of elements

Table 1. Weight ranking scale developed by authors for this research

\begin{tabular}{|c|l|l|}
\hline Rating & Description & \multicolumn{1}{c|}{ Definition } \\
\hline 10 & $\begin{array}{l}\text { Extremely } \\
\text { important }\end{array}$ & $\begin{array}{l}\text { An element very powerfully influences the success/failure of } \\
\text { commercialization of the technology. It may be essential for income/cost. }\end{array}$ \\
\hline 9 & $\begin{array}{l}\text { Very } \\
\text { important }\end{array}$ & The success/failure could cause a important income or cost. \\
\hline 7 & Important & An element can bring a minor to moderate income/cost. \\
\hline 6 & $\begin{array}{l}\text { Moderate } \\
\text { important }\end{array}$ & An element can bring a minor income/cost. \\
\cline { 1 - 2 } 4 & $\begin{array}{l}\text { Low to fair } \\
\text { important }\end{array}$ & An element can bring minimal income/cost or no harm. \\
\cline { 1 - 2 } 2 & $\begin{array}{l}\text { Slight } \\
\text { important }\end{array}$ & $\begin{array}{l}\text { An element can bring no income/cost; however, the potential for minor } \\
\text { damage exists. }\end{array}$ \\
\cline { 1 - 2 } 1 & $\begin{array}{l}\text { Not } \\
\text { important }\end{array}$ & An element can bring no harm and has no impact on cost. \\
\hline
\end{tabular}

\section{The integrated Eckenrode's Likert-type scale-based fuzzy rating approach (Turskis et al., 2019a)}

The raw rating assigned by the judge to each criterion against the scale of 0 to 10 (10 most valuable or important) treated as follows (Table 1):

$$
w_{c j}=p_{c j} / \sum_{c=1}^{m} p_{c j}
$$

where, $w_{c j}$ - weight computed for criterion $c$ from the rating given by judge $j p_{c j}$ - rating is given by judge $j$ to criterion $c$, and $\mathrm{w}_{\mathrm{c}}$ is calculated as follows:

$$
w_{c}=\sum_{j=1}^{n} w_{c j} / \sum_{j=1}^{n} \sum_{c=1}^{m} w_{c j} .
$$

The Eqs (3) and (4) using rules of fuzzy arithmetic are modified as follows: 


$$
\begin{aligned}
& \tilde{w}_{c j}=\tilde{p}_{c j} / \sum_{c=1}^{m} \tilde{p}_{c j}=\left(p_{c \alpha j} / \sum_{c=1}^{m} p_{c \gamma j} ; p_{c \beta j} / \sum_{c=1}^{m} p_{c \beta j} ; p_{c \gamma j} / \sum_{c=1}^{m} p_{c \alpha j}\right) ; \\
& \tilde{w}_{c}=\left(w_{c \alpha} ; w_{c \beta} ; w_{c \gamma}\right)=\sum_{j=1}^{n} \tilde{w}_{c j} / \sum_{j=1}^{n} \sum_{c=1}^{m} \tilde{w}_{c j}= \\
& \left(\sum_{j=1}^{n} w_{c \alpha j} / \sum_{j=1}^{n} \sum_{c=1}^{m} w_{c \gamma j} ; \sum_{j=1}^{n} w_{c \beta j} / \sum_{j=1}^{n} \sum_{c=1}^{m} w_{c \beta j} ; \sum_{j=1}^{n} w_{c \gamma j} / \sum_{j=1}^{n} \sum_{c=1}^{m} w_{c \alpha j}\right),
\end{aligned}
$$

where, $\quad w_{j l}-\min _{k} y_{j k}, j=\overline{1, n, k}=\overline{1, p}$ is minimum possible value, $w_{j \alpha}=\left(\prod_{k=1}^{p} y_{j k}\right)^{\frac{1}{p}}$, $j=\overline{1, n}, k=\overline{1, p}$ is the most possible value and $w_{j \beta}=\max _{k} y_{j k}, j=\overline{1, n}, k=\overline{1, p}$ is the maximal possible value of $j$-th criterion $w_{j \gamma}=\min _{k} y_{j k}, j=\overline{1, n}, k=\overline{1, p}$.

A defuzzification is necessary before making final decisions. A defuzzification technique a centre of gravity is used in the case study:

$$
w_{c}=\frac{1}{3}\left(w_{c \alpha}+w_{c \beta}+w_{c \gamma}\right) \text {. }
$$

The importance of elements is established, which reflects the influence of the elements on the assessed object. The evaluation of an elements and groups of elements resulted in importance for information technologies, and biotechnologies were provided in Table 2 .

Experts in the study evaluated the importance of the elements and groups of elements, and later calculations based fuzzy rating approach were made, and rankings of the elements were performed (Tables 3 and 4). The ranking is a procedure when the essential element is provided with the position equal to 1 , the second element according to importance is given 2, etc. and the last element according to importance takes rank $m$ (Zemlickienè et al., 2017). There are two main reasons for ranking popularity. First of all it's simplicity, ranking provides complex, multifaceted phenomenon of multiple image elements are summarized in a way that would be easier to assess and compare. Another reason, ranking determine changes in performance. Ranking causes both private and public organizations to question their standards (Geldres-Weiss et al., 2018). In order to clearly present the results of the research result, ranks were provided for groups of elements (Table 3). The evaluation demonstrates that the commercial potential of information technology is most influenced by groups of elements such as value for the consumer $(B)$, technology features $(E)$. Considering importance, situation in the market $(A)$ goes in the $3^{\text {rd }}$, financial environment $(C)$ in the $4^{\text {th }}$, competency of technology developers $(F)$ in the $5^{\text {th }}$, internal policy of the organization $(I)$ in the $6^{\text {th }}$, inventor/s profile $(H)$ in the $7^{\text {th }}$, competitive environment $(D)$ in the $8^{\text {th }}$ position and the last one is legal environment $(G)$.

In terms of biotechnology, technology features (E) goes in the 1st position, in the 2nd value for the consumer (B). The group of elements situation on the market $(\mathrm{A})$ is in the $3 \mathrm{rd}$ position and have the same rank for both technological fields, competence of technology developers $(F)$ is in the 4 th position, financial environment $(\mathrm{C})$ in the 5 th, legal environment (G) in the 6th, internal policy of the organization (I) in the 7th, inventor/s profile $(\mathrm{H})$ in the 8th position. In the 9 th position is competitive environment (D). 
Table 2. Description of elements meanings in the collections and the importance of elements for IT and BT (source: Zemlickiene, 2015; Lechman, 2014; Park et al., 2017; Vu et al., 2018; Mamzer et al., 2018; Volpatti \& Yetisen, 2014; Kiškis \& Limba, 2016, and own calculations based on experts research 2018-2019)

\begin{tabular}{|c|c|c|c|c|c|}
\hline \multicolumn{3}{|c|}{ Importance of elements groups } & \multirow[b]{2}{*}{ Elements } & \multicolumn{2}{|c|}{ Importance of elements } \\
\hline $\begin{array}{l}\text { Elements } \\
\text { groups }\end{array}$ & IT & BT & & IT & BT \\
\hline \multirow{3}{*}{$\begin{array}{l}\text { A-situation on } \\
\text { the market }\end{array}$} & \multirow{3}{*}{0.1181} & \multirow{3}{*}{0.1156} & $\begin{array}{l}\text { A1-target market share of the potential } \\
\text { product at the technology assessment } \\
\text { moment; }\end{array}$ & 0.5756 & 0.6162 \\
\hline & & & $\begin{array}{l}\text { A2-level of the customer's needs } \\
\text { regarding the potential product; }\end{array}$ & 0.5627 & 0.6053 \\
\hline & & & $\begin{array}{l}\text { A3-level of the readiness of the market } \\
\text { for the product; }\end{array}$ & 0.5808 & 0.6679 \\
\hline \multirow{5}{*}{$\begin{array}{l}\text { B-value for } \\
\text { the consumer }\end{array}$} & \multirow{5}{*}{0.1190} & \multirow{5}{*}{0.1164} & $\begin{array}{l}\text { B1-predicted offered value for the } \\
\text { consumer; }\end{array}$ & 0.3542 & 0.4307 \\
\hline & & & $\begin{array}{l}\text { B2-feedback of target customers } \\
\text { regarding product concept; }\end{array}$ & 0.3631 & 0.3748 \\
\hline & & & $\begin{array}{l}\text { B3-level of the uniqueness of the } \\
\text { value provided to the potential user of } \\
\text { product/technology; }\end{array}$ & 0.2986 & 0.3229 \\
\hline & & & $\begin{array}{l}\text { B4-level of experiencing difficulty in } \\
\text { using the potential product; }\end{array}$ & 0.3003 & 0.3079 \\
\hline & & & $\begin{array}{l}\text { B5-relative advantage of the potential } \\
\text { product; }\end{array}$ & 0.4119 & 0.4328 \\
\hline \multirow{7}{*}{$\begin{array}{l}\text { C-financial } \\
\text { environment }\end{array}$} & \multirow{7}{*}{0.1175} & \multirow{7}{*}{0.1152} & C1-the potential to finance; & 0.2565 & 0.1706 \\
\hline & & & C2-a competitive unit cost; & 0.2372 & 0.2189 \\
\hline & & & $\begin{array}{l}\text { C3-predicted contribution of } \\
\text { technology to the profit of the } \\
\text { company; }\end{array}$ & 0.3024 & 0.3402 \\
\hline & & & $\begin{array}{l}\text { C4-predictable period for covering } \\
\text { costs of the project on technology } \\
\text { commercialization; }\end{array}$ & 0.2927 & 0.2979 \\
\hline & & & $\begin{array}{l}\text { C5-impact of the potential product } \\
\text { durability to create a renewable source } \\
\text { of income; }\end{array}$ & 0.3037 & 0.2979 \\
\hline & & & $\begin{array}{l}\text { C6-predicted period of product } \\
\text { development; }\end{array}$ & 0.3181 & 0.2165 \\
\hline & & & $\begin{array}{l}\text { C7-accessibility of the infrastructure } \\
\text { for product development. }\end{array}$ & - & 0.2979 \\
\hline \multirow{3}{*}{$\begin{array}{l}\text { D-competitive } \\
\text { environment }\end{array}$} & \multirow{3}{*}{0.1033} & \multirow{3}{*}{0.1011} & $\begin{array}{l}\text { D1-the predicted lifetime of } \\
\text { technology; }\end{array}$ & 0.4321 & 0.5329 \\
\hline & & & D2-ability to copy technology; & 0.5626 & 0.5457 \\
\hline & & & D3-intensity of competition. & 0.5800 & 0.6047 \\
\hline
\end{tabular}


End of Table 2

\begin{tabular}{|c|c|c|c|c|c|}
\hline \multicolumn{3}{|c|}{ Importance of elements groups } & \multirow{2}{*}{ Elements } & \multicolumn{2}{|c|}{ Importance of elements } \\
\hline $\begin{array}{l}\text { Elements } \\
\text { groups }\end{array}$ & IT & BT & & IT & $\mathrm{BT}$ \\
\hline \multirow{3}{*}{$\begin{array}{l}\text { E-technology } \\
\text { features }\end{array}$} & \multirow{3}{*}{0.1189} & \multirow{3}{*}{0.1165} & E1-complexity of technology; & 0.7430 & 1.0000 \\
\hline & & & $\begin{array}{l}\text { E2-dependence of technology } \\
\text { functioning on geographical / climatic } \\
\text { circumstances; }\end{array}$ & - & 0.8946 \\
\hline & & & $\begin{array}{l}\text { E3-compatibility of the potential } \\
\text { product with the existing products. }\end{array}$ & 1.0000 & - \\
\hline \multirow{6}{*}{$\begin{array}{l}\text { F-competence } \\
\text { of technology } \\
\text { developers } \\
\text { and related } \\
\text { opportunities }\end{array}$} & \multirow{6}{*}{0.1125} & \multirow{6}{*}{0.1155} & $\begin{array}{l}\text { F1-competence of specialized } \\
\text { engineering staff; }\end{array}$ & 0.3534 & 0.32596 \\
\hline & & & $\begin{array}{l}\text { F2-competence of marketing } \\
\text { personnel; }\end{array}$ & 0.3394 & 0.32529 \\
\hline & & & $\begin{array}{l}\text { F3-competence of technology transfer } \\
\text { personnel; }\end{array}$ & 0.3316 & 0.32689 \\
\hline & & & F4-competence of sales personnel; & 0.3381 & 0.32582 \\
\hline & & & F5-competence of the production unit; & - & 0.25148 \\
\hline & & & $\begin{array}{l}\text { F6-accessibility of specialized } \\
\text { engineering staff. }\end{array}$ & 0.2780 & 0.29135 \\
\hline \multirow{6}{*}{$\begin{array}{l}\text { G-legal } \\
\text { environment }\end{array}$} & \multirow{6}{*}{0.1004} & \multirow{6}{*}{0.1150} & $\begin{array}{l}\text { G1-benevolence of national legislation } \\
\text { for commercialization; }\end{array}$ & 0.2620 & 0.2587 \\
\hline & & & G2-utilization potential of technology; & 0.2450 & 0.3041 \\
\hline & & & G3-novelty of technology; & 0.2369 & 0.0798 \\
\hline & & & $\begin{array}{l}\text { G4-significance of improvement on } \\
\text { prior art - difference compared to the } \\
\text { analogue; }\end{array}$ & 0.2478 & 0.3448 \\
\hline & & & G5-price for legal protection; & 0.2718 & 0.2939 \\
\hline & & & $\begin{array}{l}\text { G6-the influence of legal protection for } \\
\text { the development of technology. }\end{array}$ & 0.2505 & 0.3095 \\
\hline \multirow{4}{*}{$\begin{array}{l}\text { H-inventor/-s } \\
\text { profile }\end{array}$} & \multirow{4}{*}{0.1049} & \multirow{4}{*}{0.1016} & $\begin{array}{l}\text { H1-inventor's experience in technology } \\
\text { commercialization; }\end{array}$ & 0.2773 & 0.5324 \\
\hline & & & H2-inventor's academic recognition; & 0.4260 & 0.3598 \\
\hline & & & $\begin{array}{l}\text { H3-inventor's predicted level of } \\
\text { involvement as a team member in } \\
\text { technology commercialization; }\end{array}$ & 0.4627 & 0.4660 \\
\hline & & & $\begin{array}{l}\text { H4-inventor's financial contribution to } \\
\text { technology commercialization. }\end{array}$ & 0.4002 & 0.4046 \\
\hline \multirow{3}{*}{$\begin{array}{l}\text { I-internal } \\
\text { policy of the } \\
\text { institution }\end{array}$} & \multirow{3}{*}{0.1054} & \multirow{3}{*}{0.1032} & $\begin{array}{l}\text { I1-compliance of the project on } \\
\text { technology with the strategy of } \\
\text { organization; }\end{array}$ & 0.3061 & 0.6336 \\
\hline & & & $\begin{array}{l}\text { I2-acceptance of the organization } \\
\text { strategy of commercialization for the } \\
\text { inventor; }\end{array}$ & 0.5453 & 0.5308 \\
\hline & & & $\begin{array}{l}\text { I3-image of the organization in the } \\
\text { area of technology commercialization. }\end{array}$ & 0.5509 & 0.5929 \\
\hline
\end{tabular}


Table 3. Ranking importance of the elements groups for evaluation information technologies and biotechnologies (source: author based on expert scientific research results 2018-2019)

\begin{tabular}{|l|c|l|}
\hline $\begin{array}{c}\text { Ranking importance of the elements groups } \\
\text { for evaluation information technology }\end{array}$ & Ranks & $\begin{array}{c}\text { Ranking importance of the elements groups } \\
\text { for evaluation biotechnology }\end{array}$ \\
\hline B - value for the consumer & 1 & E - technology features \\
\hline E - technology features & 2 & B - value for the consumer \\
\hline A - situation in the market & 3 & A - situation in the market \\
\hline C - financial environment & 4 & $\begin{array}{l}\text { F - competence of technology developers } \\
\text { and related opportunities }\end{array}$ \\
\hline $\begin{array}{l}\text { F - competence of technology developers } \\
\text { and related opportunities }\end{array}$ & 5 & C - financial environment \\
\hline I - internal policy of the organization & 6 & G - legal environment \\
\hline H - inventor/s profile & 7 & I - internal policy of the organization \\
\hline D - competitive environment & 8 & H - inventor/s profile \\
\hline G - legal environment & 9 & D - competitive environment \\
\hline
\end{tabular}

Table 4. Ranking importance of the elements for evaluation information technologies and biotechnologies

\begin{tabular}{|c|c|c|}
\hline $\begin{array}{l}\text { Ranking importance of the elements } \\
\text { for evaluation information technology }\end{array}$ & Ranks & $\begin{array}{l}\text { Ranking importance of the elements } \\
\text { for evaluation biotechnology }\end{array}$ \\
\hline $\begin{array}{l}\text { E3 - compatibility of the potential product } \\
\text { with the existing products; }\end{array}$ & 1 & E1 - complexity of technology; \\
\hline E1 - complexity of technology; & 2 & $\begin{array}{l}\text { E2 - dependence of technology functioning } \\
\text { on geographical/climatic circumstances; }\end{array}$ \\
\hline $\begin{array}{l}\text { A3 - level of the readiness of the market for } \\
\text { the product; }\end{array}$ & 3 & $\begin{array}{l}\text { A3 - level of the readiness of the market for } \\
\text { the product; }\end{array}$ \\
\hline D3 - intensity of competition; & 4 & $\begin{array}{l}\text { I1 - compliance of the project on } \\
\text { technology with the strategy of the } \\
\text { organization; }\end{array}$ \\
\hline $\begin{array}{l}\text { A1 - target market share of the potential } \\
\text { product at the technology assessment } \\
\text { moment; }\end{array}$ & 5 & $\begin{array}{l}\text { A1 - target market share of the potential } \\
\text { product at the technology assessment } \\
\text { moment; }\end{array}$ \\
\hline $\begin{array}{l}\text { A2 - level of the customer's needs regarding } \\
\text { the potential product; }\end{array}$ & 6 & $\begin{array}{l}\text { A2 - level of the customer's needs regarding } \\
\text { the potential product; }\end{array}$ \\
\hline D2 - ability to copy technology; & 7 & D3 - intensity of competition; \\
\hline $\begin{array}{l}\text { I3 - image of the organization in the field of } \\
\text { technology commercialization; }\end{array}$ & 8 & $\begin{array}{l}\text { I3 - image of the organization in the area of } \\
\text { technology commercialization; }\end{array}$ \\
\hline $\begin{array}{l}\text { I2 - acceptance of the organization strategy } \\
\text { of commercialization for the inventor; }\end{array}$ & 9 & D2 - ability to copy technology; \\
\hline $\begin{array}{l}\mathrm{H} 3 \text { - inventor's predicted level of } \\
\text { involvement as a team member in } \\
\text { technology commercialization; }\end{array}$ & 10 & $\begin{array}{l}\text { H1- inventor's experience in technology } \\
\text { commercialization; }\end{array}$ \\
\hline D1 - predicted lifetime of technology; & 11 & D1 - predicted lifetime of technology; \\
\hline $\mathrm{H} 2$ - inventor's academic recognition; & 12 & $\begin{array}{l}\text { I2 - acceptance of the organization strategy } \\
\text { for commercialization of the inventor; }\end{array}$ \\
\hline
\end{tabular}


Continue of Table 4

\begin{tabular}{|c|c|c|}
\hline $\begin{array}{l}\text { Ranking importance of the elements } \\
\text { for evaluation information technology }\end{array}$ & Ranks & $\begin{array}{l}\text { Ranking importance of the elements } \\
\text { for evaluation biotechnology }\end{array}$ \\
\hline $\begin{array}{l}\text { B5 - relative advantage of the potential } \\
\text { product; }\end{array}$ & 13 & $\begin{array}{l}\mathrm{H} 3 \text { - inventor's predicted level of } \\
\text { involvement as a team member in } \\
\text { technology commercialization; }\end{array}$ \\
\hline $\begin{array}{l}\text { H4 - inventor's financial contribution to } \\
\text { technology commercialization. }\end{array}$ & 14 & $\begin{array}{l}\text { B5 - relative advantage of the potential } \\
\text { product; }\end{array}$ \\
\hline $\begin{array}{l}\text { B2 - feedback of target customers regarding } \\
\text { product concept; }\end{array}$ & 15 & $\begin{array}{l}\text { B1 - predicted offered value for the final } \\
\text { consumer; }\end{array}$ \\
\hline $\begin{array}{l}\text { B1 - predicted offered value for the } \\
\text { consumer; }\end{array}$ & 16 & $\begin{array}{l}\text { H4 - Inventor's financial contribution to } \\
\text { technology commercialization. }\end{array}$ \\
\hline $\begin{array}{l}\text { F1 - competence of specialized engineering } \\
\text { staff; }\end{array}$ & 17 & $\begin{array}{l}\text { B2 - feedback of target customers regarding } \\
\text { product concept; }\end{array}$ \\
\hline F2 - competence of marketing personnel; & 18 & H2 - inventor's academic recognition; \\
\hline F4 - competence of sales personnel; & 19 & $\begin{array}{l}\text { F3 - competence of technology transfer } \\
\text { personnel; }\end{array}$ \\
\hline $\begin{array}{l}\text { F3 - competence of technology transfer } \\
\text { personnel; }\end{array}$ & 20 & $\begin{array}{l}\text { F1 - competence of specialized engineering } \\
\text { staff; }\end{array}$ \\
\hline $\begin{array}{l}\text { C6 - predicted period of product } \\
\text { development; }\end{array}$ & 21 & F4 - competence of sales personnel; \\
\hline $\begin{array}{l}\text { I1 - compliance of the project on } \\
\text { technology with the strategy of the } \\
\text { organization; }\end{array}$ & 22 & F2 - competence of marketing personnel; \\
\hline $\begin{array}{l}\text { C5 - impact of the potential product } \\
\text { durability to create a renewable source of } \\
\text { income; }\end{array}$ & 23 & $\begin{array}{l}\text { G4 - significance of improvement on prior } \\
\text { art - difference compared to the analogue; }\end{array}$ \\
\hline $\begin{array}{l}\text { C3 - predicted contribution of technology } \\
\text { to the profit of the company; }\end{array}$ & 24 & $\begin{array}{l}\text { C3 - predicted contribution of technology } \\
\text { to the profit of the company; }\end{array}$ \\
\hline $\begin{array}{l}\text { B4 - level of experiencing difficulty in use } \\
\text { the potential product; }\end{array}$ & 25 & $\begin{array}{l}\text { B3 - level of the uniqueness of the value } \\
\text { provided to the potential user of product/ } \\
\text { technology; }\end{array}$ \\
\hline $\begin{array}{l}\text { B3 - level of the uniqueness of the value } \\
\text { provided to the potential user of product/ } \\
\text { technology; }\end{array}$ & 26 & $\begin{array}{l}\text { F6 - accessibility of specialized engineering } \\
\text { staff; }\end{array}$ \\
\hline $\begin{array}{l}\mathrm{C} 4 \text { - predictable period for covering } \\
\text { costs of the project on technology } \\
\text { commercialization; }\end{array}$ & 27 & $\begin{array}{l}\text { G6 - the influence of legal protection for the } \\
\text { development of technology; }\end{array}$ \\
\hline $\begin{array}{l}\text { F6 - accessibility of specialized engineering } \\
\text { staff; }\end{array}$ & 28 & $\begin{array}{l}\text { B4 - level of experiencing difficulty in using } \\
\text { the potential product; }\end{array}$ \\
\hline $\begin{array}{l}\text { H1 - inventor's experience in technology } \\
\text { commercialization; }\end{array}$ & 29 & G2 - utilization potential of technology; \\
\hline G5 - price for legal protection; & 30 & $\begin{array}{l}\text { C4 - predictable period for covering } \\
\text { costs of the project on technology } \\
\text { commercialization; }\end{array}$ \\
\hline $\begin{array}{l}\text { G1 - benevolence of national legislation for } \\
\text { commercialization; }\end{array}$ & 33 & $\begin{array}{l}\text { C5 - impact of the potential product } \\
\text { durability in order to create a renewable } \\
\text { source of income; }\end{array}$ \\
\hline
\end{tabular}


End of Table 4

\begin{tabular}{|l|c|l|}
\hline $\begin{array}{c}\text { Ranking importance of the elements } \\
\text { for evaluation information technology }\end{array}$ & Ranks & \multicolumn{1}{|c|}{$\begin{array}{c}\text { Ranking importance of the elements } \\
\text { for evaluation biotechnology }\end{array}$} \\
\hline C1 - the potential to finance; & 32 & $\begin{array}{l}\text { C6 - predicted period of product } \\
\text { development; }\end{array}$ \\
\hline $\begin{array}{l}\text { G6-the influence of legal protection for the } \\
\text { development of technology; }\end{array}$ & 33 & G5 - price for legal protection; \\
\hline G2 - utilization potential of technology; & 34 & F5 - competence of the production unit; \\
\hline $\begin{array}{l}\text { G4 - significance of improvement on prior } \\
\text { art - difference compared to the analogue; }\end{array}$ & 35 & $\begin{array}{l}\text { G1 - benevolence of national legislation for } \\
\text { commercialization; }\end{array}$ \\
\hline C2 - a competitive unit cost; & 36 & C2 - a competitive unit cost; \\
\hline G3 - novelty of technology; & 37 & $\begin{array}{l}\text { C7 - accessibility to the infrastructure for } \\
\text { product development; }\end{array}$ \\
\hline- & 38 & C1 - the potential to finance; \\
\hline- & 39 & G3 - novelty of technology. \\
\hline
\end{tabular}

The evaluation demonstrates that the commercial potential of information technologies and biotechnologies are most influenced by elements such as technology features (E) and value for the consumer (B). The highest contrast can be seen in terms of the legal environment $(G)$. For biotechnology, the legal environment $(G)$ is significantly more important than information technology. This result of the research was not surprising but confirmed the specificity of different technological fields that have been mentioned in the scientific literature.

Both in terms of information technology and biotechnology regarding the importance of all elements, regardless of the group of elements (Table 4). Thus, 1st position concerning information technology have element compatibility of the potential product with the existing products (E3), $2^{\text {nd }}$ position has the complexity of technology (E1). $1^{\text {st }}$ position concerning biotechnology have element complexity of technology (E1), $2^{\text {nd }}$ position has element dependence of technology functioning on geographical/climatic circumstances (E2). Some elements of biotechnology and information technology are in the same place. Although the number of elements in these collections of technologies varies slightly, the collection of information technologies consists of thirty-seven (37) elements and the collections of biotechnology elements consists of thirty-nine (39) elements. However, coincidence shows that certain elements have a similar influence on the expediency of commercialization for both technological fields: element level of the readiness of the market for the product (A3) takes the $3^{\text {rd }}$ position; element target market share of the potential product at the technology assessment moment $(A 1)$ takes the $5^{\text {th }}$ position; element level of the customer's needs regarding the potential product (A2) takes the $6^{\text {th }}$ position; element image of the organization in the field of technology commercialization (I3) takes the $8^{\text {th }}$ position; element predicted the lifetime of technology (D1) takes the $11^{\text {th }}$ position; element predicted contribution of technology to the profit of the company (C3) takes the $24^{\text {th }}$ position; element a competitive unit cost $(C 2)$ takes the $36^{\text {th }}$ position.

The research aims to identify differences in the evaluation of the commercial potential of these two technological fields. Scientific research has shown that the highest contrast between information technology (IT) and biotechnology (BT) are collections concerning these elements: 
An element Inventor's experience in technology commercialization (H1) takes the 29th position for IT and $10^{\text {th }}$ position for BT, ranks difference between these technological fields are nineteen (19) positions. An element Compliance of the project on technology with the strategy of the organization (I1) takes $22^{\text {nd }}$ position for IT and $4^{\text {th }}$ position for BT, ranks difference are eighteen (18) positions. An element Predicted period of product development (C6) takes $21^{\text {st }}$ position for IT and $6^{\text {th }}$ position for BT, ranks difference is fifteen (15) positions. An element Significance of improvement on prior art-difference compared to the analogue (G4) takes $35^{\text {th }}$ for IT and $23^{\text {rd }}$ position for BT, ranks difference between these technological fields are twelve (12) positions. An element Impact of the potential product durability to create a renewable source of income (C5) takes $23^{\text {rd }}$ position for IT and $33^{\text {rd }}$ position for BT ranks difference is ten (12) positions. An element Inventor's academic recognition (H2) takes $12^{\text {th }}$ position for IT and $18^{\text {th }}$ for BT. Ranks difference are six (6) positions. An element the influence of legal protection for the development of technology (G6) takes $33^{\text {rd }}$ position for IT, and $27^{\text {th }}$ position for BT ranks difference is five (5) positions. An element the potential to finance (C1) takes $32^{\text {nd }}$ position for IT and $38^{\text {th }}$ position for BT, ranks difference is five (5) positions.

\section{Conclusions}

The successful commercialization of technology in a real environment is influenced by many complex procedural, social, economic, political and technological elements and the result of commercialization is affected differently. The best choices can be found by applying mathematical methods for processing and calculating large amounts of information. A important problem for each R\&D company is the prevention of irrational use of resources, which dominate in this market. The commercialization of different technological fields is individual. Therefore the specifics of each of them are necessary when evaluating the expediency of technology commercialization. Based on the previously developed universal collection of elements, details of information technology and biotechnology fields and expert insights, new elements collections for information technology and biotechnology have been proposed. Some elements were already included in universal collection of elements. Certain elements it was decided to include in the collection of elements, based on the specifics of mentioned technologies. In most cases, the same elements are relevant for both technological fields, which means that between information technology and biotechnology the collections of elements differ slightly.

The evaluation demonstrates that the commercial potential of information technologies and biotechnologies are mainly influenced by the elements groups such as technology features $(E)$, value for the consumer $(B)$. In terms of information technologies, considering importance, situation in the market $(A)$ goes in the $3^{\text {rd }}$, competence of technology developers and related opportunities $(\mathrm{F})$ - in the $4^{\text {th }}$, competency of technology developers $(F)-$ in the $5^{\text {th }}$, internal policy of the organization $(I)$ - in the $6^{\text {th }}$, inventor/s profile - in the $7^{\text {th }}$, competitive environment $(D)$ - in the $8^{\text {th }}$ position. In terms of biotechnologies, technology features $(E)$ goes in the $1^{\text {st }}$ position, in the $2^{\text {nd }}$ value for the consumer $(B)$. The group of elements situation on the market $(A)$ is in the $3^{\text {rd }}$ position and have the same rank for both technological fields, competence of technology developers $(F)$ is in the $4^{\text {th }}$ position, financial environment $(C)$ in the 5 th, legal environment $(G)$ in the $6^{\text {th }}$, internal policy of the organization $(I)$ in the $7^{\text {th }}$, inventor/s profile $(H)$ in the 8 th position. In the 9 th position is competitive environment $(D)$. 
In the previous study was offered the universal collection of elements and the importance of these groups of elements and element was identified. However, another method was used to establish the importance of the elements: the experts expressed their position on the importance of system elements: a position on the importance of provided groups of elements and elements was asked to be taken thus distributing $100 \%$ among possible groups of elements and elements; later the coefficient of concordance was calculated. The surveyed experts were selected considering: 1) experience in the process of technology commercialization in Lithuania; 2) and positions held by the experts in the institutions developing technologies as well as in the establishments responsible for the promotion and control of technology commercialization. The results of the evaluation of the element groups as well as the rating order were provided: in the 1st position were value for a consumer $(B=0.178)$; in the 2 nd - competitive environment $(D=0.155)$; in the 3rd - current situation on the market $(A=0.139)$; in the 4 th - competence of technology developers $(F=0.138)$; in the 5 th - financial environment $(C=0.105)$; in the 6 th - characteristics of technology $(E=0.104)$; in the 7 th - circumstances related to an inventor/inventors $(H=0.072)$; in the $8^{\text {th }}-$ legal environment $(G=0.065)$; in the $9^{\text {th }}-$ internal policy of the institution $(I=0.043)$.

In the current study an elements show the main differences in the evaluation of the commercial potential of these two technological fields: Inventor's experience in technology commercialization (H1); Compliance of the project on technology with the strategy of the organization (I1); Predicted period of product development (C6); Significance of improvement on prior art - difference compared to the analogue (G4); Impact of the potential product durability in order to create a renewable source of income (C5); Inventor's academic recognition (H2); the influence of legal protection for the development of technology (G6); the potential to finance (C1).

The results of the study confirmed the authors' insights on the element the influence of legal protection for the development of technology (G6), in the case of information technology, this element is in position $33^{\text {rd }}$, in the case of biotechnology, this is the $27^{\text {th }}$ position.

The collections of elements for evaluation the commercial potential of technologies and detected importance of elements are useful as a guidelines for technology developers, potential owners and investors in the decision-making processes of commercialization, investment or purchase of technology. Later the collection of elements and detected importance of elements will be used at the next stage of research on developing a models for assessing the commercial potential of technologies. The developed models to evaluate the commercial potential of information technologies and biotechnologies should be used by organizations engaged in $\mathrm{R} \& \mathrm{D}$ to support the expedience of technology commercialization and to make a correct decision on commercialization regarding technology portfolio. Also, this model can be used as a tool for identifying technology commercialization prospects by different stakeholders looking for investment opportunities in technology and the acquisition of technology.

\section{Acknowledgements}

This project has received funding from European Social Fund (project No 09.3.3-LMTK-712-02-0201) under grant agreement with the Research Council of Lithuania (LMTLT). 


\section{References}

Allen, D. E., McAleer, M., \& Singh, A. K. (2017). Risk measurement and risk modelling using applications of Vine copulas. Sustainability, 9(10), 1762. https://doi.org/10.3390/su9101762

Bagočius, V., Zavadskas, E. K., \& Turskis, Z. (2014). Multi-person selection of the best wind turbine based on the multi-criteria integrated additive-multiplicative utility function. Journal of Civil Engineering and Management, 20(4), 590-599. https://doi.org/10.3846/13923730.2014.932836

Belton, V., \& Stewart, T. (2002). Multiple criteria decision analysis: An integrated approach. Kluwer Academic Publishers. https://doi.org/10.1007/978-1-4615-1495-4

Buckley, J. J. (1984). The multiple judge, multiple criteria ranking problem: a fuzzy set approach. Fuzzy Sets and Systems, 13(1), 25-37. https://doi.org/10.1016/0165-0114(84)90024-1

Dubois, D., \& Prade, H. (1978). Operations on fuzzy numbers. International Journal of Systems Science, 9(6), 613-626. https://doi.org/10.1080/00207727808941724

Dziallas, M., \& Blind, K. (2019). Innovation indicators throughout the innovation process: An extensive literature analysis. Technovation. 80-81, 3-29. https://doi.org/10.1016/j.technovation.2018.05.005

Eckenrode, R. T. (1965). Weighting multiple criteria. Management Science, 12(3), 180-192. https://doi.org/10.1287/mnsc.12.3.180

European Commission. (2010). Communication from the Commission to the European Parliament, the council, the European Economic and social committee and the committee of the regions "A Digital Agenda for Europe". COM(2010)245, May 2010. Brussels. https://eur-lex.europa.eu/LexUriServ/ LexUriServ.do?uri=COM:2010:0245:FIN:EN:PDF

Geldres-Weiss, V. V., Joaquín Monreal-Pérez, J., Tornavoi-Carvalho D., \& Tello-Gamarra J. (2018). A new measure of international product innovation. Contemporary Economics, 12(4), 367-380. https://doi.org/10.2139/ssrn.3377276

Ghassemi, A., \& Darvishpour, A. (2018). A novel approach for risk evaluation and risk response planning in a geothermal drilling project using DEMATEL and fuzzy ANP. Decision Science Letters, 7(3), 225-242. https://doi.org/10.5267/j.dsl.2017.10.001

Hashemkhani Zolfani, S., Zavadskas, E. K., \& Turskis, Z. (2013). Design of products with both International and Local perspectives based on Yin-Yang balance theory and SWARA method. Economic Research-Ekonomska Istraživanja, 26(2), 153-166. https://doi.org/10.1080/1331677X.2013.11517613

International Telecommunication Union (ITU). (2012). Measuring the Information Society 2012. Geneva: ITU. http://www.itu.int/ITU-D/ict/publications/idi/material/2012/MIS2012_without_Annex_4.pdf

Keršuliene, V., Zavadskas, E. K., \& Turskis, Z. (2010). Selection of rational dispute resolution method by applying new step-wise weight assessment ratio analysis (SWARA). Journal of Business Economics and Management, 11(2), 243-258. https://doi.org/10.3846/jbem.2010.12

Keshavarz-Ghorabaee, M., Amiri, M., Zavadskas, E. K., Turskis, Z., \& Antucheviciene, J. (2018). An extended step-wise weight assessment ratio analysis with symmetric interval type-2 fuzzy sets for determining the subjective weights of criteria in multi-criteria decision-making problems. Symmetry, 10(4), 91. https://doi.org/10.3390/sym10040091

Kiškis, M., \& Limba, T. (2016). Biotechnologiju MVI intelektinès nuosavybès strategijos (Monografija). Mykolas Romeris University.

Leberling, H. (1981). On finding compromise solution in multi-criteria problems using the fuzzy minoperator. Fuzzy Sets System, 6(2), 105-110. https://doi.org/10.1016/0165-0114(81)90019-1

Lechman, E. (2014). ICT diffusion trajectories and economic development: Empirical evidence for 46 developing countries. In H. Kaur \& X. Tao (Eds.), ICTs and the millennium development goals: A United Nations perspective. Springer, Boston, MA. https://doi.org/10.1007/978-1-4899-7439-6_2 
Likert, R. (1932). A technique for the measurement of attitudes. Archives of Psychology, 140(22), 1-55.

Maghsoodi, A. I., Maghsoodi, A. I., Poursoltan, P., Antucheviciene, J., \& Turskis, Z. (2019). Dam construction material selection by implementing the integrated SWARA-CODAS approach with targetbased attributes. Archives of Civil and Mechanical Engineering, 19(4), 1194-1210. https://doi.org/10.1016/j.acme.2019.06.010

Mamzer, M. F., Sophie Duboisb, S., \& Saoutc, Ch. (2018). How to strengthen the presence of patients in health technology assessments conducted by the health authorities? Therapie, 73, 95-105. https://doi.org/10.1016/j.therap.2017.11.004

Montagnier P., \& Wurthmann A. (2011). Digital divide: From computer access to online activities - A micro data analysis (OECD Digital Economy Papers, No. 189). OECD Publishing.

Nakhaei, J., Bitarafan, M., Lale Arefi, S. \& Kapliński, O. (2016). Model for rapid assessment of vulnerability of office buildings to blast using SWARA and SMART methods (a case study of Swiss Re Tower). Journal of Civil Engineering and Management, 22(6), 831-843. https://doi.org/10.3846/13923730.2016.1189457

Park, J. H., Kim, Y. B., \& Kim, M. K. (2017). Investigating factors influencing the market success or failure of IT services in Korea. International Journal of Information Management, 37(1), 1418-1427. https://doi.org/10.1016/j.ijinfomgt.2016.10.004

Pérez, J. A. H., Galdes, C., Kunc, M. H., \& Flores, A. (2019). New approach to the innovation process in emerging economies: The manufacturing sector case in Chile and Peru. Technovation, 79, 35-55. https://doi.org/10.1016/j.technovation.2018.02.012

Saaty, T. L. (1980). The analytic hierarchy process: Planning, priority setting, resources allocation. McGraw.

Saaty, T. L. (1996). Decision making with dependence and feedback: The analytic network process. RWS Publications.

SearchDataCenter. (2018). Information technology (IT). Definition. https://searchdatacenter.techtarget. com/definition/IT

Silvestre, B. S., \& Țîrcă, D. M. (2019). Innovations for sustainable development: Moving toward a sustainable future. Journal of Cleaner Production, 208, 325-332.

https://doi.org/10.1016/j.jclepro.2018.09.244

Turskis, Z., Dzitac, S., Stankiuviene, A., \& Šukys, R. (2019a). A fuzzy group decision-making model for determining the most influential persons in the sustainable prevention of accidents in the construction SMEs. International Journal of Computers Communications \& Control, 14(1), 90-106. https://doi.org/10.15837/ijccc.2019.1.3364

Turskis, Z., Goranin, N., Nurusheva, A., \& Boranbayev, S. (2019b). Information security risk assessment in critical infrastructure: A hybrid MCDM approach. Informatica, 30(1), 187-211. https://doi.org/10.15388/Informatica.2019.203

Turskis, Z., Goranin, N., Nurusheva, A., \& Boranbayev, S. (2019c). A fuzzy WASPAS-based approach to determine critical information infrastructures of EU sustainable development. Sustainability, 11(2), 424. https://doi.org/10.3390/su11020424

Turskis, Z., Lazauskas, M., \& Zavadskas, E. K. (2012). Fuzzy multiple criteria assessment of construction site alternatives for non-hazardous waste incineration plant in Vilnius city, applying ARAS-F and AHP methods. Journal of Environmental Engineering and Landscape Management, 20(2), 110-120. https://doi.org/10.3846/16486897.2011.645827

Turskis, Z., Zavadskas, E. K., Antucheviciene, J., \& Kosareva, N. (2015). A hybrid model based on fuzzy AHP and fuzzy WASPAS for construction site selection. International Journal of Computers Communications \& Control, 10(6), 113-128. https://doi.org/10.15837/ijccc.2015.6.2078 
Van Laarhoven, P. J. M., \& Pedrycz, W. (1983). A fuzzy extension of Saaty's priority theory. Fuzzy Sets and Systems, 11(1-3), 229-241. https://doi.org/10.1016/S0165-0114(83)80082-7

Vechkinzova, E., Petrenko Y., Benčič S., Ulybyshev D., \& Zhailauov, Y. (2019). Entrepreneurship and Sustainability Issues, 7(1), 498-509. https://doi.org/10.9770/jesi.2019.7.1(35)

Volpatti, L. R., \& Yetisen, A. K. (2014). Commercialization of microfluidic devices. Trends in Biotechnology, 32(7), 347-350. https://doi.org/10.1016/j.tibtech.2014.04.010

Vu, Ch. H. T., Lee, H. G., Chan, Y. K., \& Oh, H. M. (2018). Axenic cultures for microalgal biotechnology: establishment, assessment, maintenance, and applications. Biotechnology Advances, 36(2), 380-396. https://doi.org/10.1016/j.biotechadv.2017.12.018

Whinney, M. D. (1971). Christopher Wren. Praeger Publishers, New York.

Zadeh, L. A. (1965). Fuzzy sets. Information and Control, 8(3) 338-353. https://doi.org/10.1016/S0019-9958(65)90241-X

Zavadskas, E. K., Antucheviciene, J., Saparauskas, J., \& Turskis, Z. (2013a). MCDM methods WASPAS and MULTIMOORA: Verification of robustness of methods when assessing alternative solutions. Economic Computation and Economic Cybernetics Studies and Research, 47(2), 5-20.

Zavadskas, E. K., Kaklauskas, A., Turskis, Z., \& Kalibatas, D. (2009). An approach to multi-attribute assessment of indoor environment before and after refurbishment of dwellings. Journal of Environmental Engineering and Landscape Management, 17(1), 5-11. https://doi.org/10.3846/1648-6897.2009.17.5-11

Zavadskas, E. K., Turskis, Z., Volvačiovas, R., \& Kildiene, S. (2013b). Multi-criteria assessment model of technologies. Studies in Informatics and Control, 22(4), 249-258. https://doi.org/10.24846/v22i4y201301

Zavadskas, E. K., \& Vilutienė, T. (2006). A multiple criteria evaluation of multi-family apartment block's maintenance contractors: I - Model for maintenance contractor evaluation and the determination of its selection criteria. Building and Environment, 41(5), 621-632, 2006. https://doi.org/10.1016/j.buildenv.2005.02.019

Zemlickiene, V. (2015). Assessment of the commercial potential of technologies (Doctoral Dissertation). Vilnius Gediminas Technical University, Lithuania.

Zemlickienè, V., Mačiulis, A., \& Tvaronavičienè, M. (2017). Factors impacting the commercial potential of technologies: Expert approach. Technological and Economic Development of Economy, 23(2), 410-427. https://doi.org/10.3846/20294913.2016.1271061 